\title{
Effects of primary productivity on beta diversity of ecological communities
}

Efeitos da produtividade primária na diversidade beta de comunidades ecológicas

Leticia Siman Bora ${ }^{1}$, Juliana Wojciechowski ${ }^{2}$, Jaqueline Dittrich ${ }^{1}$ and André Andrian Padial ${ }^{1,2 *}$ (if

${ }^{1}$ Núcleo de Pesquisa em Limnologia, Ictiologia e Aquicultura - NUPELIA, Programa de Pós-graduação em Ecologia de Ambientes Aquáticos Continentais, Universidade Estadual de Maringá - UEM, Av. Colombo, 5790, Zona 7, CEP 87020-900, Maringá, PR, Brasil

${ }^{2}$ Setor de Ciências Biológicas, Laboratório de Análise e Síntese em Biodiversidade, Programa de Pós-graduação em Ecologia e Conservação, Departamento de Botânica, Universidade Federal do Paraná - UFPR, Av. Cel. Francisco H. dos Santos, 100, Jardim das Américas, CEP 81530-000, Curitiba, PR, Brasil

*e-mail: aapadial@gmail.com

Cite as: Bora, L.S., et al. Effects of primary productivity on beta diversity of ecological communities. Acta Limnologica Brasiliensia, 2019, vol. 31, e23

Abstract: Aim: Several ecological factors are predicted to affect beta diversity - the dissimilarity of communities among localities or through time. Considering the effect of primary productivity, there is a divergence in the literature concerning if it is positive, negative or hump-shaped. This is relevant considering the discussion on the role of primary productivity on deterministic and stochastic processes shaping ecological communities. The main goal of this study was to review ecological literature to explore causes for variation in the predominant relationship between beta diversity and primary productivity. Methods: We have performed a scientometric analysis following the PRISMA statement for systematic reviews and the articles search was made through the ISI Web of Science ${ }^{\circledR}$ database. Results: The number of articles approaching the relationship between beta diversity and primary productivity is growing more than expected by the natural growth in published articles. From the 465 articles found, only 38 directly dealt with beta diversity-productivity relationship. From them, we extracted 76 relationships, most of them positive, in almost all factors analyzed. Even so, the proportion of negative studies was higher in aquatic environments. In the Afrotropic region, only negative relationships in terrestrial studies were found. There is a clear inclination towards studies regarding large spatial scales, terrestrial environments, with vertebrates and in the Neartic or Paleartic regions. In aquatic environments there was a clear dominance of studies using small-body organisms, contrasting with terrestrial studies that used more often vertebrates and plants. Conclusions: There is an increasing interest in studies concerning this relationship. Positive relations can be explained by several ecological factors, and the more common negative relationships in aquatic environments can be explained by the fact that productivity can cause eutrophication. We also pointed out gaps in the knowledge, especially considering studies in small and medium spatial scales, groups beyond plants and vertebrates in terrestrial environments, and aquatic studies in Afrotropic and Indo - Malaya regions.

Keywords: nutrient enrichment; community variation; scientometrics; stochasticity; environmental determinism; global analysis.

Resumo: Objetivo: Diversos fatores ecológicos afetam previsivelmente a diversidade beta - a dissimilaridade das comunidades entre locais ou através do tempo. Considerando o efeito da produtividade primária, existem divergências na literatura a respeito do tipo de relaçáo que seria 
encontrada (positiva, negativa ou em formato de domo). Isto é relevante considerando a discussão do papel da produtividade primária na mudança das comunidades ecológicas através de processos determinísticos e estocásticos. $\mathrm{O}$ objetivo principal deste estudo foi elucidar a relação predominante encontrada entre a diversidade beta e a produtividade primária em artigos publicados, e quais fatores poderiam influenciar tal relação (escala, ambiente, organismo ou região biogeográfica). Métodos: Realizamos uma análise cienciométrica seguindo o protocolo PRISMA para revisóes sistemáticas. A busca dos artigos foi realizada através da base de dados ISI Web of Science ${ }^{\circledR}$. Resultados: O número de artigos abordando a relação entre a diversidade beta e a produtividade primária está crescendo ao longo do tempo mais do que o crescimento natural da ciência. Dos 465 artigos encontrados, somente 38 lidaram diretamente com a relação entre a diversidade beta e produtividade. Nestes 38 artigos, 76 relaçóes foram encontradas, e a maioria destas foi positiva, em praticamente todos os fatores analisados. Somente relaçóes negativas e estudos terrestres foram encontrados na região Afrotropical. Fica claro um viés para estudos com escalas grandes, ambientes terrestres, com vertebrados e nas regióes Neárticas e Paleárticas. Em ambientes aquáticos houve uma clara dominância dos estudos envolvendo invertebrados e micro-organismos/fungos. Conclusóes: $\mathrm{O}$ interesse em estudos envolvendo esta relação está aumentando. Relações positivas foram mais frequentemente encontradas nesta cienciometria. Lacunas no conhecimento foram evidenciadas, como a falta de estudos em escalas pequenas e médias, grupos além de plantas e vertebrados em ambientes terrestres, e estudos aquáticos nas regióes dos Afrotrópicos e Indo-Malaya.

Palavras-chave: enriquecimento de nutrientes; variaçáo da comunidade; cienciometria; estocasticidade; determinismo ambiental; análise global.

\section{Introduction}

Comprehending the mechanisms that determine biodiversity in biological communities is a major goal in Ecology and is essential to prevent impacts of anthropogenic actions on diversity (Chase $\&$ Leibold, 2002). Such concern is particularly relevant in aquatic ecosystems, which have both a high biological diversity (Balian et al., 2008) and suffer with high extinction rates (Jenkins, 2003). Indeed, one of the most concerning ecological impacts, both in aquatic and terrestrial environments, is known as biotic homogenization - the decrease in beta diversity through space and/or time (McKinney \& Lockwood, 1999; Olden \& Poff, 2003). Relatedly, community ecologists have been focusing in identifying determinants of beta diversity (Melo et al., 2011), including the nature of processes shaping community variation (Heino et al., 2015b). Stochastic and deterministic processes may interact determining beta diversity (Chase, 2010; Heino et al., 2015a). Deterministic processes are related to species filtering, supported by the theoretical background of the niche theory. As more heterogeneous environments support more opportunities to explore resources, it is expected a greater number of species in a heterogeneous landscape. On the other hand, stochastic processes include ecological drift, limits of species dispersion and colonization and extinction dynamics as drivers of differences among communities (Chase, 2010; Heino et al., 2015a).

Primary productivity (carbon rate fixed by photosynthesis) is one of the main determinants of biodiversity and, therefore, exerts great influence on beta diversity. Previous studies have generated strong evidence that increasing primary productivity causes an increase in the frequency of stochastic processes (Chase \& Leibold, 2002; Chase, 2010). Productivity can also be considered a measure of environmental heterogeneity, since its increase can promote species coexistence by avoiding competitive exclusion and, as a consequence, is one of the main factors responsible for heterogeneous distribution of biodiversity (Chase $\&$ Leibold, 2002). A competitive exclusion, for instance, is avoided when productivity leads to a saddle between superior competitors and other species that share the same resources, having the potential to create multiple states of equilibria (Chase \& Leibold, 2003).

Even so, the relationship between primary productivity and the components of biodiversity is variable and seems to be context-dependent. For instance, Chase \& Leibold (2002) have suggested that, at local scales, alpha diversity tends to increase with productivity until it reaches a peak and then tends to decrease (hump-shaped relationship). On the other hand, in regional scales, this relationship tends to be linear and positive (Chase \& Leibold, 2002). Relatedly, previous studies have shown that increases in primary productivity generate higher beta diversity (Hawkins et al., 2003; Chase, 2010). This could be explained by the increase in the energy input on the system, which would increase the frequency of stochastic processes, as greater colonization or extinction rates and ecological drifts on large regional populations, 
causing higher variation in species among localities (Hawkins et al., 2003; Chase, 2010). However, others previous works demonstrated that increases in productivity can have a negative impact on beta diversity, particularly in aquatic ecosystems, homogenizing the community when an organism or group of organisms is favored in locations with excess of nutrients, i.e. in eutrophic aquatic environments (Donohue et al., 2009). In this case, the rationale is based on the fact that nutrient concentration on the water column is frequently used as a proxy for primary productivity in aquatic ecosystems (Howarth, 1998). Nevertheless, although it is possible to evaluate the relationship between diversity and productivity using proxies for productivity, there are many studies that use direct measures of net primary productivity (Liu et al., 2016; Burkle et al., 2015).

Summarizing studies on the relationship between primary productivity and beta diversity is essential to understand the mechanisms that affect this component of biodiversity in ecologically distinct environments (see also Chase \& Ryberg, 2004). Due to the divergences considering the results of the studies on the relationship between primary productivity and beta diversity, we have made a scientometric analysis aiming to elucidate its predominant direction and review the main factors (spatial scale, biological group or biogeographic region) that appear to affect the direction of beta diversity-primary productivity relationship. Also, given the major problem that aquatic environments face with eutrophication, it would be expected that most studies would find a negative relationship between primary productivity and beta- diversity in aquatic realm even that it is not always true (e.g. Chase \& Ryberg, 2004; Thrush et al., 2010). In that matter, the scientometric analysis also assists to discover if there is a clear pattern of the relationship in this environment, and the possible differences between the relationships found in aquatic and terrestrial environments, as the factors that could influence them.

\section{Methods}

\subsection{Articles search and screening}

We followed PRISMA statement for systematic reviews (Moher et al., 2009; see Appendix 1). The articles search was made through the ISI Web of Science ${ }^{\circledR}$ database using the following keywords: ("beta divers*" OR "communit* variat*" OR "beta-divers*" OR "communit* dissimil*”) AND (product* OR eutroph* OR "nutrient enrich*") in the topic in August 2016. All articles obtained on the search were screened based on their titles and abstracts. Only those articles that directly approached the relationship between metacommunity beta diversity and productivity were included in our database, in agreement to the examples "Mission Statement V4b” (MSV4b) e "Mission Statement T6” (MST6) of Anderson et al. (2011); which basically reflect in the relationship between predictor variables (in our case, productivity proxies) and overall variation of a set of communities. In this case, we selected articles that did estimate one value of beta diversity to each point of a productivity gradient for posterior analysis. Articles that evaluated simply correlation between compositional dissimilarity among communities (another way to evaluate beta diversity) and dissimilarity on productivity levels of locations were dismissed (i.e., "Mission Statements T3", "Mission Statement T4", or "Mission Statement V3", Anderson et al., 2011).

\subsection{Comparison among studies}

To evaluate temporal trends in articles, we plotted the total number of articles registered on the search and those retained after the screening against years. For that, we controlled temporal increase in scientific publications by dividing found articles by the total number of articles indexed on ISI Web of Science ${ }^{\circledR}$ for each year. The journals that published about the relationship between beta diversity and productivity, and their impact factor (JCR from ISI Web of Science ${ }^{\circledR}$ ) (Web of Science, 2015) were then evaluated. A Friedman test was made to compare the medians of journal's impact factors and the median impact factor on the Ecology area (1.972, available for 2013).

All articles retained in our database were analyzed based on: (i) the predominant relationship between primary productivity and beta diversity; (ii) the spatial scale used on the study (considering area or extension: small $=1-100 \mathrm{~km}^{2}$ or until $14 \mathrm{~km}$, medium $=101-1000 \mathrm{~km}^{2}$ or $14-45 \mathrm{~km}$; or large $>1001 \mathrm{~km}^{2}$, or $>45 \mathrm{~km}$ ), (iii) the biological group studied (plants, vertebrates, invertebrates, or microorganisms/fungus); (iv) the type of environment inhabited by the group (aquatic or terrestrial); and (v) the biogeographic region of the study (according to Ecoregions described in World Wildlife Fund, 2006). The comparison between aquatic and terrestrial environments was made by dividing the beta diversity - primary productivity relationships found in the selected articles between 
those environments and separating them by the other categories mentioned above (ii, iii, and v). In this case, we compared proportion of relationships in each class using a chi-square test with Monte Carlo simulations (Hope, 1968). All graphics were generated on STATISTICAv 7.1 (Statsoft Inc, 2005) software.

\section{Results}

A total of 465 articles were found. After the screening, only $8 \%(n=38)$ indeed evaluated the relationship between beta diversity and primary productivity according to MSV4b and MST6 (Appendix 2). Many articles were dismissed for demonstrating only the presence of variation of communities in a gradient of productivity, and did not demonstrate how much beta diversity changed with increases in productivity.

There was a temporal increase on the interest about the relationship between beta diversity and productivity, considering both the totality of articles on the search and only those filtered after screenings described on the methods (Figure 1). The 38 selected articles were published on 23 journals. The medium impact factor of journals used to publish the filtered articles was 3.232, significantly higher than the medium impact factor of journals in the Ecology area (Friedman test: $Q=18.69, P<0.001$ ). The frequency of articles by journal is shown on Figure 2.

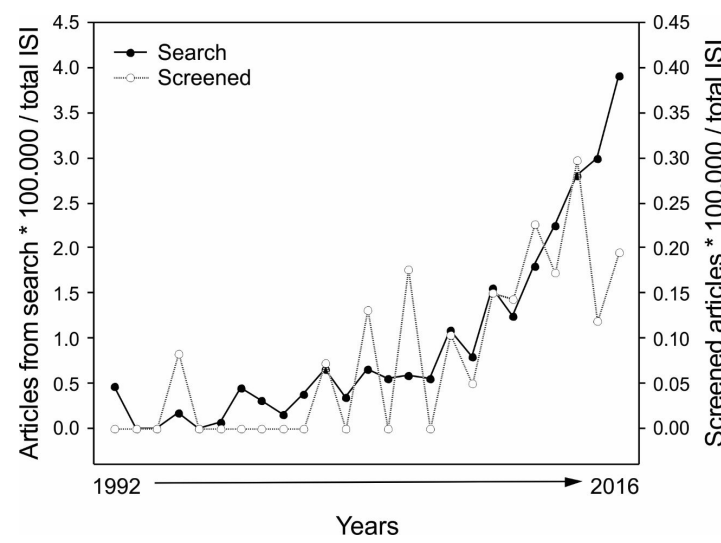

Figure 1. Increases on the number of articles published about beta diversity and productivity, found on the search (axis Y - left) on Isi Web of Science ${ }^{\circledR}$ database, and screened after the selection (axis $\mathrm{Y}$ - right), in relation with the total number of indexed articles each year. NOTE: Symbol * on axis $\mathrm{Y}$ is referred to the multiplication of the articles by $100.000 /$ total of articles in ISI Web of Science.
76 relationships between primary productivity and beta diversity were observed in the 38 articles. That was due to the fact that different relationships were found when some articles analyzed more than one region or different spatial scales. Regarding the observed relationships between primary productivity and beta diversity, 43 were positive (32 in terrestrial, 10 in aquatic environments and 1 using modeling approach), 16 negative ( 8 in terrestrial and 8 in aquatic environments), 14 neutral (or without relation; 9 in terrestrial and 5 in aquatic environments), 2 hump-shaped ( 1 in aquatic and 1 on terrestrial environments) and 1 concave-up (or inversed hump- shaped in terrestrial environment). In some articles, it was not possible to determine the spatial scale or region of the study with accuracy, and therefore some relationships were not included in some of the further analysis.

Many primary productivity proxies were used to test the relationship: nutrient concentrations,

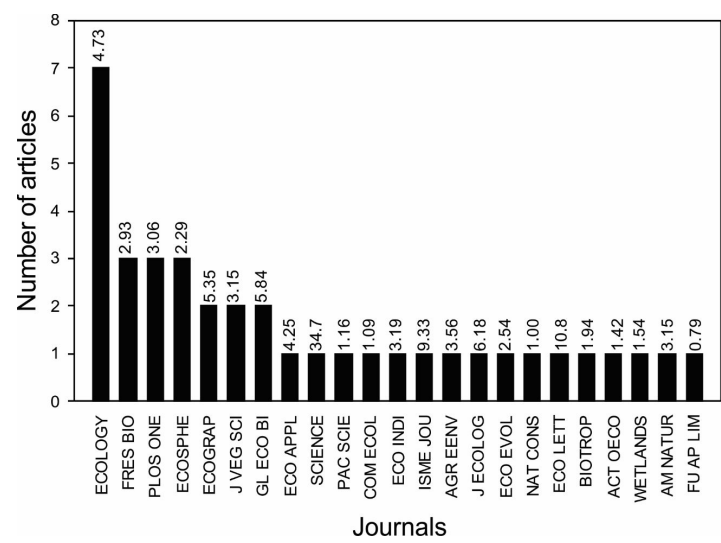

Figure 2. Frequencies of publication of the 38 articles selected after systemic screening in relation with the newspapers on which they were published. Note: Values above the bars indicate journal impact factor (JCR from ISI Web of Science ${ }^{\circledR}$ ) (Web of Science, 2015). Abbreviated journals: FRES $\mathrm{BIO}=$ Freshwater Biology; ECOSPHE: Ecosphere; ECOGRAP: Echography; J VEG SCI: Journal of Vegetation Science; GL ECO BI: Global Ecology and Biogeography; ECO APPL: Ecological Applications; PAC SCIE: Pacific Science; COM ECOL: Community Ecology; ECO INDI: Ecological Indicators; ISME JOU: Isme Journal; AGR EENV: Agricultural Ecosystems \& Environment; J ECOLOG: Journal of Ecology; ECO EVOL: Ecology and Evolution; NAT CONS: Natureza \& conservação; ECO LETT: Ecology Letters; BIOTROP: Biotropica; ACT OECO: Acta Oecologica International Journal of Ecology; AM NATUR: American Naturalist; FU AP LIM: Fundamental and Applied Limnology. 
evapotranspiration potential, fertilization, amount of chlorophyll a, among others. In one of the articles selected (Liu et al., 2016), different proxies had different responses: a positive relationship was observed using the coefficient of variation of annual primary productivity (C.V. of ANPP), and a neutral relationship was observed using directly the ANPP. A summary of relationships features is shown in Figure 3.

When the proportion (not absolute number) of positive, negative and neutral relationships are compared among terrestrial and aquatic environments, the pattern is similar, but with a weak tendency of having more negative relationships in aquatic environments (Figure 4). The proportion of studies in medium and large spatial scales was higher in terrestrial environments than aquatic, however in small spatial scales the proportion of studies in aquatic systems was slightly higher than terrestrial (Figure 4). Terrestrial studies often used larger organisms for studies (i.e. vertebrates or plants) while aquatic studies utilized in its majority invertebrates and microorganisms/fungus (Figure 4). Terrestrial studies were more common in most ecoregions, and proportion did not vary among regions (Figure 4). However, it is important to note that only terrestrial studies were found in Afrotropics and Indo - Malaya regions; and the only study in Antarctic was performed in an aquatic environment. For this reason, they were not included in Chi-square test: obviously, there is a bias in the environment never studied in these three ecoregions - aquatic or terrestrial.

\section{6 relationships $(100 \%)$}

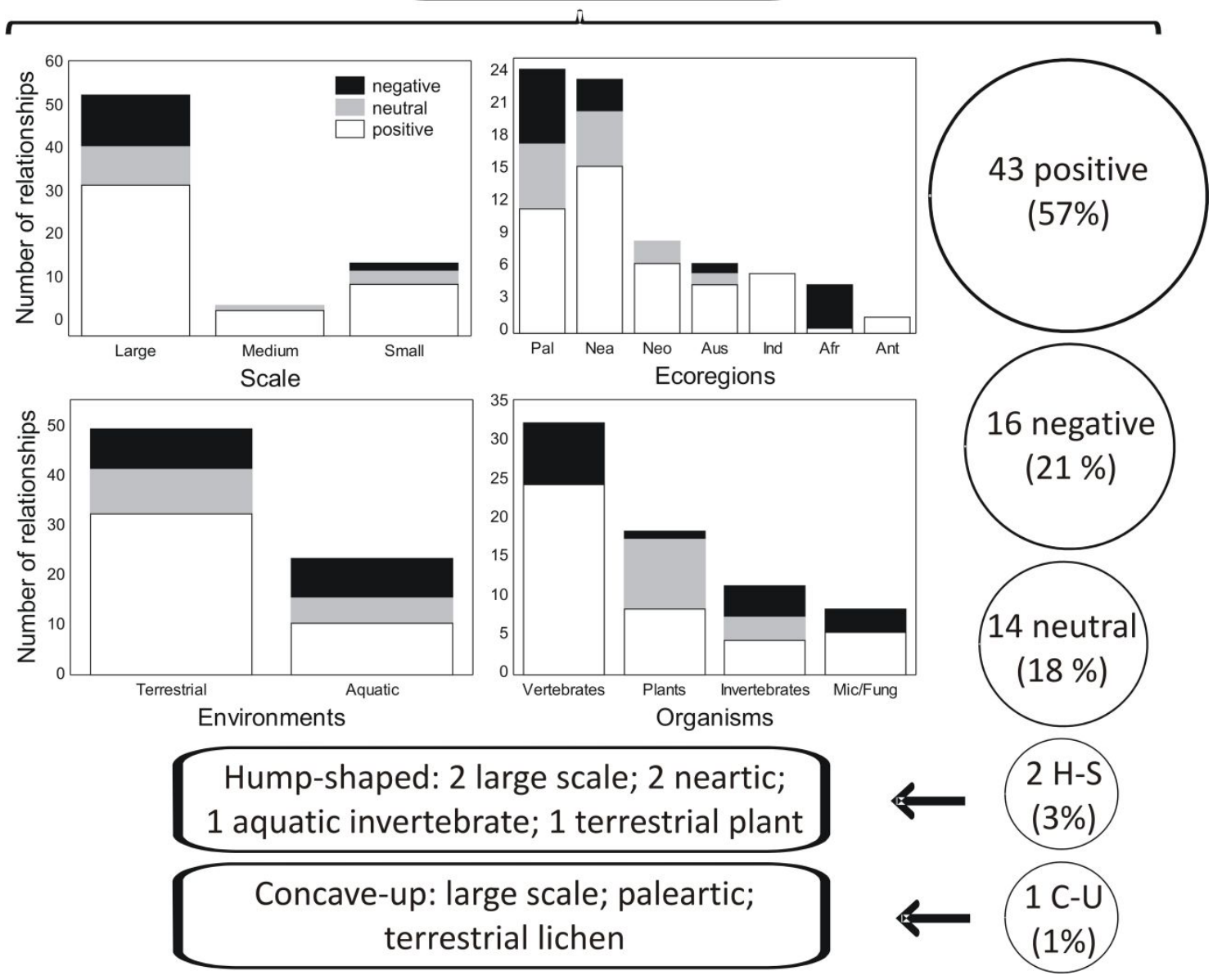

Figure 3. Distribution of 76 relationships between productivity and beta diversity found in 38 articles, divided by relationship type (positive, negative, hump-shapped or other), and separated by spatial scales, ecoregions, environments and organisms. NOTE: The complete table with all relationships characteristics is available in Supplementary material, and the map illustrating the ecoregions is available in Appendix 2. Ecorregions abbreviated: Pal = Paleactic, Nea $=$ Nearctic, Neo $=$ Neotropicacs, Aus = Australasia, Ind = Indo-Malaya, Afr $=$ Afrotropics, Ant $=$ Antarctic Biological groups abbreviated: Mic/Fung = Microorganisms/Fungus. 

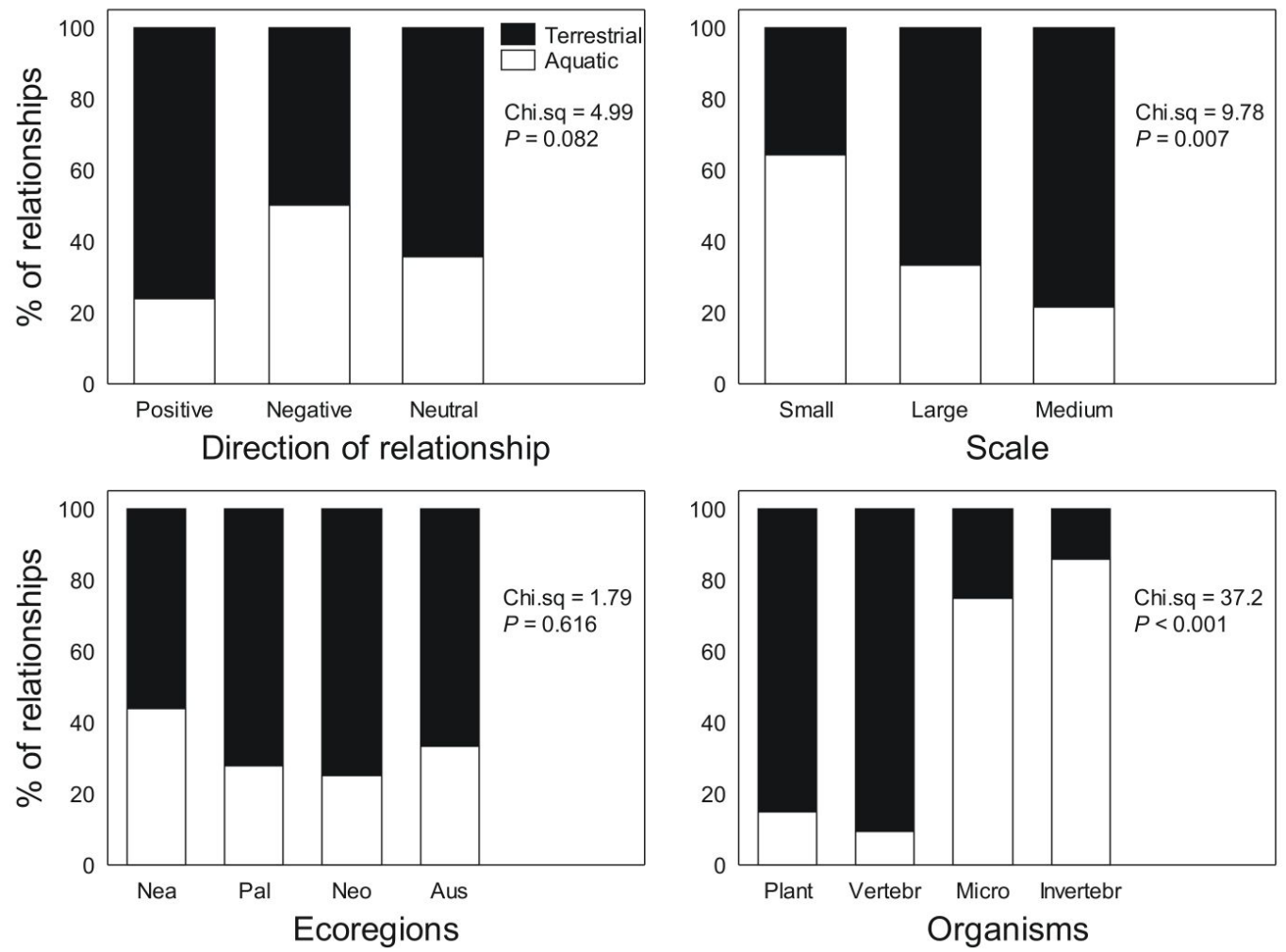

Figure 4. Distribution of the relationships between productivity and beta diversity found in the 38 articles, divided by terrestrial and aquatic environments, and separated by direction of relationships (upper left), spatial scales (upper right), ecoregions (lower left) and organisms (lower right). Results from a Chi-square test with Monte Carlo simulations (see Methods) are shown. For ecoregions, the Indo-Malaya, Afrotropics and Antarctic are not shown given they had studies only in either aquatic (Antartic) or Terrestrial (Indo-Malaya and Afrotropics) environments. Biological groups abbreviated: Plant $=$ Plants; Vertebr $=$ Vertebrates; Micro $=$ Microorganisms $/$ Fungus, Invertebr $=$ Invertebrates . Ecorregions abbreviated: $\mathrm{Nea}=$ Nearctic, $\mathrm{Pal}=$ Paleactic, $\mathrm{Neo}=$ Neotropicacs, Aus $=$ Australasia .

\section{Discussion}

We have demonstrated important features on studies involving the relationship between productivity and beta diversity. Firstly, it is interesting that although among the almost 500 articles found in the search, only 38 publications actually analyzed the relationship above mentioned until 2016. This clearly demonstrates a shortage in publications about this important issue in Ecology. As in most issues regarding biodiversity, the majority of studies involve alpha diversity, although the interest in beta diversity is increasing in the last years (Harrison et al., 2011; Kitayama, 2012). Indeed, the stepped increase in articles did reinforce the interest of ecologists in understanding the role of productivity in beta diversity. Finally, the high median impact factor of the journals in which the articles were published also suggests high relevancy of such issue in ecological science.
Considering all information available, we did demonstrate that relationships between productivity and beta diversity were mostly positive in almost all factors (spatial scale, environment, biological group and ecoregion). That agrees with Chase's work (2010), which suggests increases in stochastic processes with increasing productivity, which therefore increase spatial dissimilarity (i.e. beta diversity). Besides the importance of stochasticity, deterministic processes also can generate positive relationships when high levels of productivity lead to niche based increases in beta-diversity (Stegen et al., 2012). Due to the low number of studies, it is important to continue to seek in which situations (organisms, regions and scale) some relationship seems to be more important. Nevertheless, given positive relationships were more common, it predominates in almost all situations. Even so, we also suggest that the relationship between primary productivity and beta diversity is dependent on the 
organism and spatial scale considered (see also Chase \& Leibold, 2002).

Even so, positive relationships are not a universal pattern. For example, in Afrotropic regions, none of the 4 reported relationships were positive. It also contradicts theories that beta diversity would be higher in tropical regions that usually present high primary productivity (Harrison et al., 2006). On the other hand, the negative relationships found in this ecoregion might be a consequence of the desert climate in the north of Africa (Qian \& Xiao, 2012). The opposite pattern occurred in the Neotropics and Indo-Malaya regions, where no negative relationship was found, agreeing with theories of higher beta diversity in tropical regions (Harrison et al., 2006). Even so, one cannot exclude a publication bias, in which results in agreement with consolidated theories tend to be better accepted in journals (Lortie et al., 2007). Comparing environments, the evidence (albeit weak) that negative relationships are relatively more common in aquatic environment could be related to eutrophication, a long-term central issue in limnology (e.g. Carpenter, 1981; Dodds et al., 2009). Unfortunately, given the lack of methods standardization and the few information in articles found in our systematic review, we could not perform meta-analytical methods (Borenstein et al., 2009) that could be used to compare effect sizes of negative and positive relationships.

The region with fewer studies was Antarctic, which is understandable given its remoteness (Thrush et al., 2010). The opposite occurs with Nearctic and Palearctic regions, that presented the highest number of studies involving primary productivity and beta diversity; probably due to the fact that these are developed regions (such as United States and Europe), and naturally perform more researches and publish a greater number of articles annually (May, 1997). The fact that the proportion of studies in ecoregions is similar for aquatic and terrestrial environments may indicate that there is no geographical bias in studies, although terrestrial studies are always more common. Even so, it is important to note that the ecoregions with few studies do not have studies in both environments (Afrotropics, Indo-Malaya and Antartic), so the recommendation to increase studies in both environment remains for such ecoregions that are historically less studied (Trimble \& van Aarde, 2012).

It is interesting that hump-shaped relationships were found only in large spatial scales. Although not evaluating beta diversity, Bonn et al. (2004) also found a hump-shaped relationship between diversity and productivity in groups of African birds. It makes sense, given that at larger spatial scales, the productivity gradient may also be high. In this case, low productive sites may have limiting diversity due to lack of resources, and a positive relationship is initially expected. However, if productivity is too high, this can be a disturbance that may favor few tolerant species, explaining the decrease in diversity at high levels of productivity, which is expected particularly in aquatic environments (Donohue et al., 2009). Even so, it is relevant to note the low number of studies in small scales, and most of them being conducted in aquatic environments. Maybe an increase in research may also describe hump-shaped relationships in small and medium spatial scales. We do consider the low number of studies in smaller scales an evidenced gap on the knowledge of this relationship, particularly in terrestrial habitats. Indeed, management actions usually are made at small and medium scales. This fact also indicates the low frequency of experimental studies, which are central to interpret causality in relationships (Resetarits \& Bernardo, 2005). On the other hand, our results may also suggest that large-scale studies are more uncommon in aquatic habitats, which is expected due to the fact that aquatic environments have more clear limits - the watersheds, which is a challenge for macro ecological studies, for instance (Beck et al., 2012).

There was also a clear tendency of studies involving plants and, mostly, vertebrates in the totality of articles selected (interestingly, no study on vertebrates presented neutral relationship on this scientometric analyzes). On the other hand, other biological groups are less studied, which is also a general pattern in ecological studies (Orlikowska et al., 2016). It is also interesting that the group most frequently analyzed depended on the environment. An explanation for large-body groups (i.e. plants and vertebrates) being mostly evaluated in terrestrial environment can also relate with a larger proportion of macro ecological studies - which are both conducted more frequently in terrestrial environments and used biological databases better established (plants and vertebrates; see Beck et al., 2012). On the other hand, it is expected that, relatively to plants and vertebrates, invertebrates and other microorganisms were better studied in aquatic environments, given their importance for mechanisms associated to productivity and beta diversity, such as eutrophication (Donohue et al., 2009; Chase, 2010). Astonishingly, the only study 
that utilized lichens to evaluate the relationship between primary productivity and beta diversity presented an unusual relationship: concave-up. This may suggest that besides the great capacity of dispersion of lichens, their capacity of persistence in environments is severely affected in very high or very low levels of productivity (see also Virtanen et al., 2013). Anyway, this example also suggests that further studies in less popular ecological groups may improve ecological knowledge on the effects of productivity in biodiversity.

It is noticeable that aquatic environments are the least studied, reflecting a pattern found in other works and reinforcing the gap in knowledge regarding studies on aquatic environments, when compared to terrestrial (Orlikowska et al., 2016). At the same time, there is a long-standing concern on anthropogenic impacts in freshwater and marine ecosystems, mainly related to artificially increased productivity due to eutrophication (Smith et al., 2006; Schindler \& Vallentyne, 2008; Donohue et al., 2009) and biotic homogenization (Villéger et al., 2011). Aquatic ecologists must increase their effort considering such issue.

Although it was difficult to establish patterns of the relationships in different situations, our work evidenced clear patterns on publications involving beta diversity and primary productivity. It is noticeable that the interest on the relationship between primary productivity and beta diversity has been growing in the last years. Furthermore, the articles were published in newspapers of high visibility, given the high impact factors of the journals that published about the relationship. The majority of relationships between primary productivity and beta diversity were positive in practically all factors of scale, biological group, environment and ecoregion analyzed, with exception of Afrotropics and invertebrates. Ecoregions and biological groups seemed to differ in their predominant direction of the relationship. More than finding overall patterns, we also suggest gaps in knowledge that must be filled in further studies. Relatively few studies involving small and medium spatial scales, aquatic environments, regions beyond the Nearctic and Palearctic and groups beyond plants and vertebrates in terrestrial environments were found. Also, there was a considerable lack of aquatic studies in Afrotropics and Indo - Malaya regions. We do encourage further studies in those topics, particularly given the severe changes in productivity of almost all ecosystems due to anthropogenic interferences.

\section{Acknowledgements}

A. A. Padial acknowledges CNPq for continuous financial support (Process Numbers: 307984/2015-0 and 402828/2016-0). J. Wojciechowski, J. Dittrich and L. S. Bora also acknowledge CAPES for student scholarships. Finally, we are grateful for A. Camargo, I. Bianchini and an anonymous reviewer for valuables comments on a previous draft of this manuscript.

\section{References}

ANDERSON, M.J., CRIST, T.O., CHASE, J.M., VELLEND, M., INOUYE, B.D., FREESTONE, A.L., SANDERS, N.J., CORNELL, H.V., COMITA, L.S., DAVIES, K.F., HARRISON, S.P., KRAFT, N.J., STEGEN, J.C. and SWENSON, N.G. Navigating the multiple meanings of $\beta$ diversity: a roadmap for the practicing ecologist. Ecology Letters, 2011, 14(1), 19-28. http://dx.doi.org/10.1111/ j.1461-0248.2010.01552.x. PMid:21070562.

BALIAN, E.V., SEGERS, H., LÉVÉQUE, C. and MARTENS, K. The freshwater animal diversity assessment: an overview of the results. Hydrobiologia, 2008, 595(1), 627-637. http://dx.doi.org/10.1007/ s10750-007-9246-3.

BECK, J., BALLESTEROS-MEJIA, L., BUCHMANN, C.M., DENGLER, J., FRITZ, S.A., GRUBER, B., HOF, C., JANSEN, F., KNAPP, S., KREFT, H., SCHNEIDER, A., WINTER, M. and DORMANN, C.F. What's on the horizon for macroecology? Ecography, 2012, 35(8), 673-683. http://dx.doi. org/10.1111/j.1600-0587.2012.07364.x.

BONN, A., STORCH, D. and GASTON, K.J. Structure of the species-energy relationship. Proceedings. Biological Sciences, 2004, 271(1549), 1685-1691. http://dx.doi.org/10.1098/rspb.2004.2745. PMid:15306288.

BORENSTEIN, M., HEDGES, L.V., HIGGINS, J.P.T. and ROTHSTEIN, H.R. Introduction to metaanalysis. West Sussex: John Willey \& Sons, Ltd., 2009. http://dx.doi.org/10.1002/9780470743386.

BURKLE, L.A., MYERS, J.A. and BELOTE, T.T. Wildfire disturbance and productivity as drivers of plant species diversity across spatial scales. Ecosphere, 2015, 6(10), 202. http://dx.doi.org/10.1890/ES1500438.1.

CARPENTER, S.R. Submersed vegetation: an internal factor in lake ecosystem succession. American Naturalist, 1981, 118(3), 372-383. http://dx.doi. org/10.1086/283829.

CHASE, J.M. and LEIBOLD, M.A. 2003. Ecological Niches: Linking Classical and Contemporary Approaches, Univ. of Chicago Press, Chicago. http://dx.doi.org/10.7208/ chicago/9780226101811.001.0001. 
CHASE, J.M. and LEIBOLD, M.A. Spatial scale dictates the productivity-biodiversity relationship. Nature, 2002, 416(6879), 427-430. http://dx.doi. org/10.1038/416427a. PMid:11919631.

CHASE, J.M. and RYBERG, W.A. Connectivity, scale dependence, and the productivity-diversity relationship. Ecology Letters, 2004, 7(8), 676683. http://dx.doi.org/10.1111/j.14610248.2004.00622.x.

CHASE, J.M. Stochastic community assembly causes higher biodiversity in more productive environments. Science, 2010, 328(5984), 1388-1391. http://dx.doi. org/10.1126/science.1187820. PMid:20508088.

DODDS, W.K., BOUSKA, W.W., EITZMANN, J.L., PILGER, T.J., PITTS, K.L., RILEY, A.J., SCHLOESSER, J.T. and THORNBRUGH, D.J. Eutrophication of U.S. freshwaters: analysis of potential economic damages. Environmental Science \& Technology, 2009, 43(1), 12-19. http://dx.doi. org/10.1021/es801217q. PMid:19209578.

DONOHUE, I., JACKSON, A.L., PUSCH, M.T. and IRVINE, K. Nutrient enrichment homogenizes lake benthic assemblages at local and regional scales. Ecology, 2009, 90(12), 3470-3477. http://dx.doi. org/10.1890/09-0415.1. PMid:20120814.

HARRISON, S., DAVIES, K.F., SAFFORD, H.D. and VIERS, J.H. Beta diversity and the scale-dependence of the productivity-diversity relationship: a test in the Californian serpentine flora. Journal of Ecology, 2006, 94(1), 110-117. http://dx.doi.org/10.1111/j.13652745.2005.01078.x.

HARRISON, S., VELLEND, M. and DAMSCHEN, E.I. 'Structured' beta diversity increases with climatic productivity in a classic dataset. Ecosphere, 2011, 2(1), art11. http://dx.doi.org/10.1890/ES10-00095.1.

HAWKINS, B.A., FIELD, R., CORNELL, H.V., CURRIE, D.J., GUEGAN, J.-F., KAUFMAN, D.M., KERR, J.T., MITTELBACH, G.G., OBERDORFF, T., O'BRIEN, E.M., PORTER, E.E. and TURNER, J.R.G. Energy, water, and broadscale patterns of species richness. Ecology, 2003, 84(12), 3105-3117. http://dx.doi.org/10.1890/038006.

HEINO, J., MELO, A.S. and BINI, L.M. Reconceptualising the beta diversity-environmental heterogeneity relationship in running water systems. Freshwater Biology, 2015a, 60(2), 223-235. http:// dx.doi.org/10.1111/fwb.12502.

HEINO, J., MELO, A.S., SIQUEIRA, T., SOININEN, J., VALANKO, S. and BINI, L.M. Metacommunity organisation, spatial extent and dispersal in aquatic systems: patterns, processes and prospects. Freshwater Biology, 2015b, 60(5), 845-869. http://dx.doi. org/10.1111/fwb.12533.

HOPE, A.C.A. A simplified Monte Carlo significance test procedure. Journal of the Royal Statistical Society.
Series B. Methodological, 1968, 30(3), 582-598. http://dx.doi.org/10.1111/j.2517-6161.1968. tb00759.x.

HOWARTH, R.W. Nutrient limitation of net primary production in marine ecosystems. Annual Review of Ecology and Systematics, 1998, 19(1), 89-110. http:// dx.doi.org/10.1146/annurev.es.19.110188.000513.

INFOESCOLA [viewed 22 Dec. 2017]. Biogeografia [online]. 2010. Available from: https://www. infoescola.com/ciencias/biogeografia/

JENKINS, M. Prospects for biodiversity. Science, 2003, 302(5648), 1175-1177. http://dx.doi.org/10.1126/ science.1088666. PMid:14615529.

KITAYAMA, K. Beta diversity of tree species along soil-p gradients in tropical montane rain forests of contrasting species pools: does biodiversity matter in stabilizing forest ecosystems? Pacific Science, 2012, 66(2), 151-160. http://dx.doi.org/10.2984/66.2.5.

LIU, L., CHENG, J., LIU, Y. and SHENG, J. Relationship of productivity to species richness in the xinjiang temperate grassland. PLoS One, 2016, 11(4), e0154026. http://dx.doi.org/10.1371/journal. pone.0154026. PMid:27100676.

LORTIE, C.J., AARSSEN, L.W., BUDDEN, A.E., KORICHEVA, J.K., LEIMU, R. and TREGENZA, T. Publication bias and merit in ecology. Oikos, 2007, 116(7), 1247-1253. http://dx.doi.org/10.1111/ j.2007.0030-1299.15686.x.

MAY, R.M. The scientific wealth of nations. Science, 1997, 275(5301), 793-796. http://dx.doi.org/10.1126/ science.275.5301.793.

MCKINNEY, M.L. and LOCKWOOD, J.L. Biotic homogenization: a few winners replacing many losers in the next mass extinction. Trends in Ecology \& Evolution, 1999, 14(11), 450-453. http:// dx.doi.org/10.1016/S0169-5347(99)01679-1. PMid:10511724.

MELO, A.S., SCHNECK, F., HEPP, L.U., SIMÓES, N.R., SIQUEIRA, T. and BINI, L.M. Focusing on variation: methods and applications of the concept of beta diversity in aquatic ecosystems. Acta Limnologica Brasiliensia, 2011, 23(3), 318-331. http://dx.doi. org/10.1590/S2179-975X2012005000010.

MOHER, D., LIBERATI, A., TETZLAFF, J. and ALTMAN, D.G. Preferred reporting items for systematic reviews and meta-analyses: the PRISMA statement. PLoS Medicine, 2009, 6(7), e1000097. http://dx.doi.org/10.1371/journal.pmed.1000097. PMid:19621072.

OLDEN, J.D. and POFF, N.L. Toward a mechanistic understanding and prediction of biotic homogenization. American Naturalist, 2003, 162(4), 442-460. http://dx.doi.org/10.1086/378212. PMid:14582007.

ORLIKOWSKA, E.H., ROBERGE, J.-M., BLICHARSKA, M. and MIKUSIŃSKI, G. 
Gaps in ecological research on the world's largest internationally coordinated network of protected areas: a review of Natura 2000. Biological Conservation, 2016, 200, 216-227. http://dx.doi.org/10.1016/j. biocon.2016.06.015.

QIAN, H. and XIAO, M. Global patterns of the beta diversity-energy relationship in terrestrial vertebrates. Acta Oecologica, 2012, 39, 67-71. http://dx.doi. org/10.1016/j.actao.2011.12.003.

RESETARITS, W.J. and BERNARDO, J. Experimental ecology: issues and perspectives. Oxford: Oxford University Press, 2005, pp 488.

SCHINDLER, D. W. and VALLENTYNE, J.R. The algal bowl: overfertilization of the world's freshwaters and estuaries. Edmonton: University of Alberta Press, 2008.

SMITH, V.H., JOYE, S.B. and HOWARTH, R.W. Eutrophication of freshwater and marine ecosystems. Limnology and Oceanography, 2006, 51(1 part 2), 351-355. http://dx.doi.org/10.4319/lo.2006.51.1_ part_2.0351.

STATSOFT INC. [viewed 22 Dec. 2017]. Statistica (data analysis software system), version 7.1 [online]. Tulsa: Statsoft Inc., 2005. Available from: www.statsoft.com

STEGEN, J.C., LIN, X., KONOPKA, A.E. and FREDRICKSON, J.K. Stochastic and deterministic assembly processes in subsurface microbial communities. The ISME Journal, 2012, 6(9), 16531664. http://dx.doi.org/10.1038/ismej.2012.22. PMid:22456445.

THRUSH, S.F., HEWITT, J.E., CUMMINGS, V.J., NORKKO, A. and CHIANTORE, M. B-diversity and species accumulation in antarctic coastal benthos: influence of habitat, distance and productivity on ecological connectivity. PLoS One, 2010, 5(7), e11899. http://dx.doi.org/10.1371/journal. pone.0011899. PMid:20689578.

TRIMBLE, M.J. and VAN AARDE, R.J. Geographical and taxonomic biases in research on biodiversity in human-modified landscapes. Ecosphere, 2012, 3(12), 1-16. http://dx.doi.org/10.1890/ES12-00299.1.

VILLÉGER, S., BLANCHET, S., BEAUCHARD, O., OBERDORFF, T. and BROSSE, S. Homogenization patterns of the world's freshwater fish faunas. Proceedings of the National Academy of Sciences of the United States of America, 2011, 108(44), 18003-18008. http://dx.doi.org/10.1073/ pnas.1107614108. PMid:22025692.

VIRTANEN, R., GRYTNES, J.-A., LENOIR, J., LUOTO, M., OKSANEN, J., OKSANEN, L. and SVENNING, J.-C. Productivity-diversity patterns in arctic tundra vegetation. Ecography, 2013, 36(3), 331-341. http://dx.doi.org/10.1111/j.16000587.2012.07903.x.

WEB OF SCIENCE [viewed 22 Dec. 2017]. Journal Citation Reports $^{\circledR}$ [online]. USA: Thomson Reuters, 2015. Available at https://www.webofknowledge. com/

WORLD WILDLIFE FUND. [viewed 22 Dec. 2017]. WildFinder: online database of species distributions [online]. Washington: WWF, 2006. Available from: http://www.worldwildlife.org/wildfinder

Received: 22 December 2017 Accepted: 02 August 2019 
Appendix 1. PRISMA 2009 flow diagram.
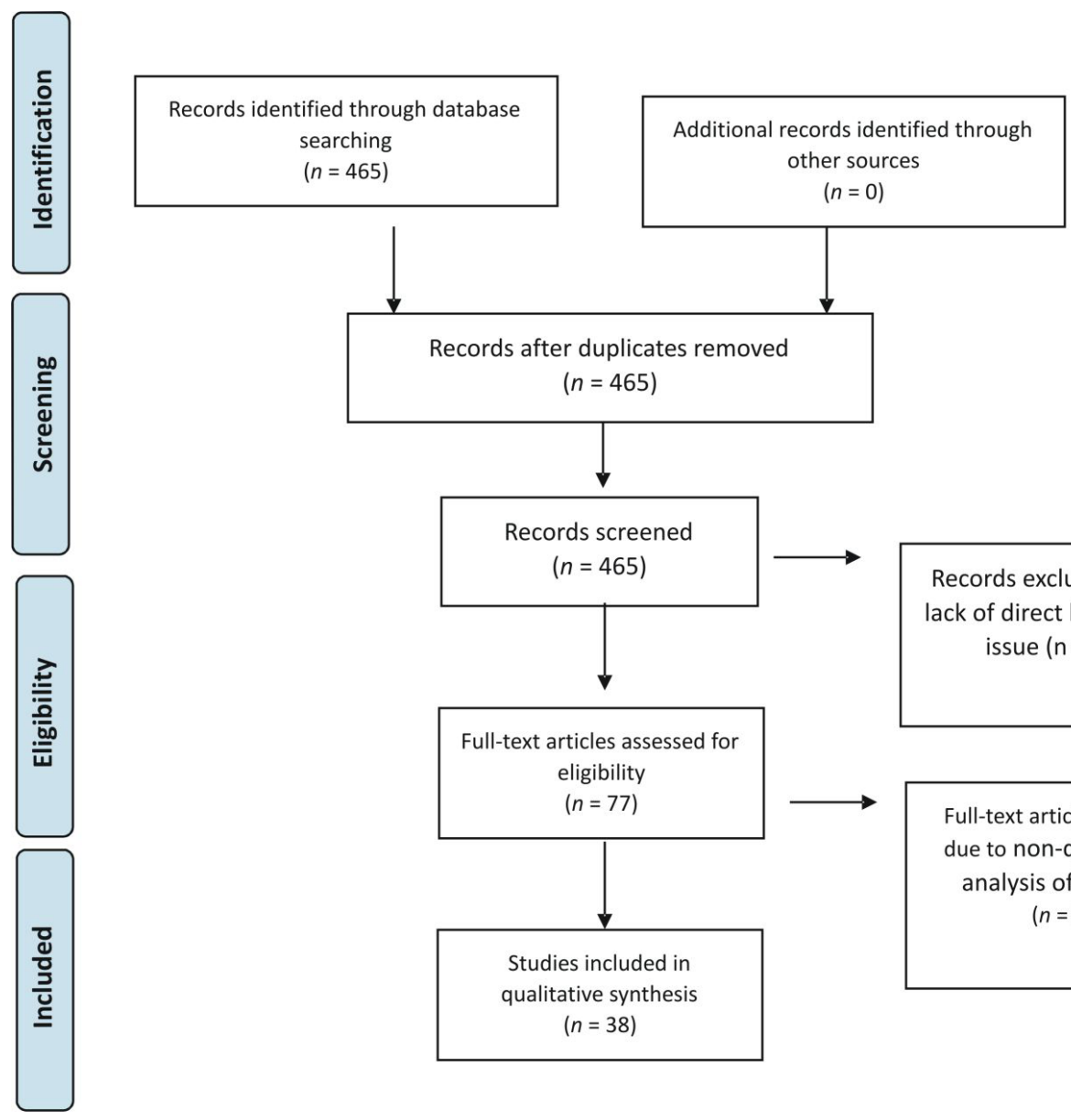

Records excluded due to lack of direct link with the issue $(n=388)$

Full-text articles excluded due to non-quantitative analysis of the issue $(n=39)$

Appendix 2. Map illustrating the ecorregions.

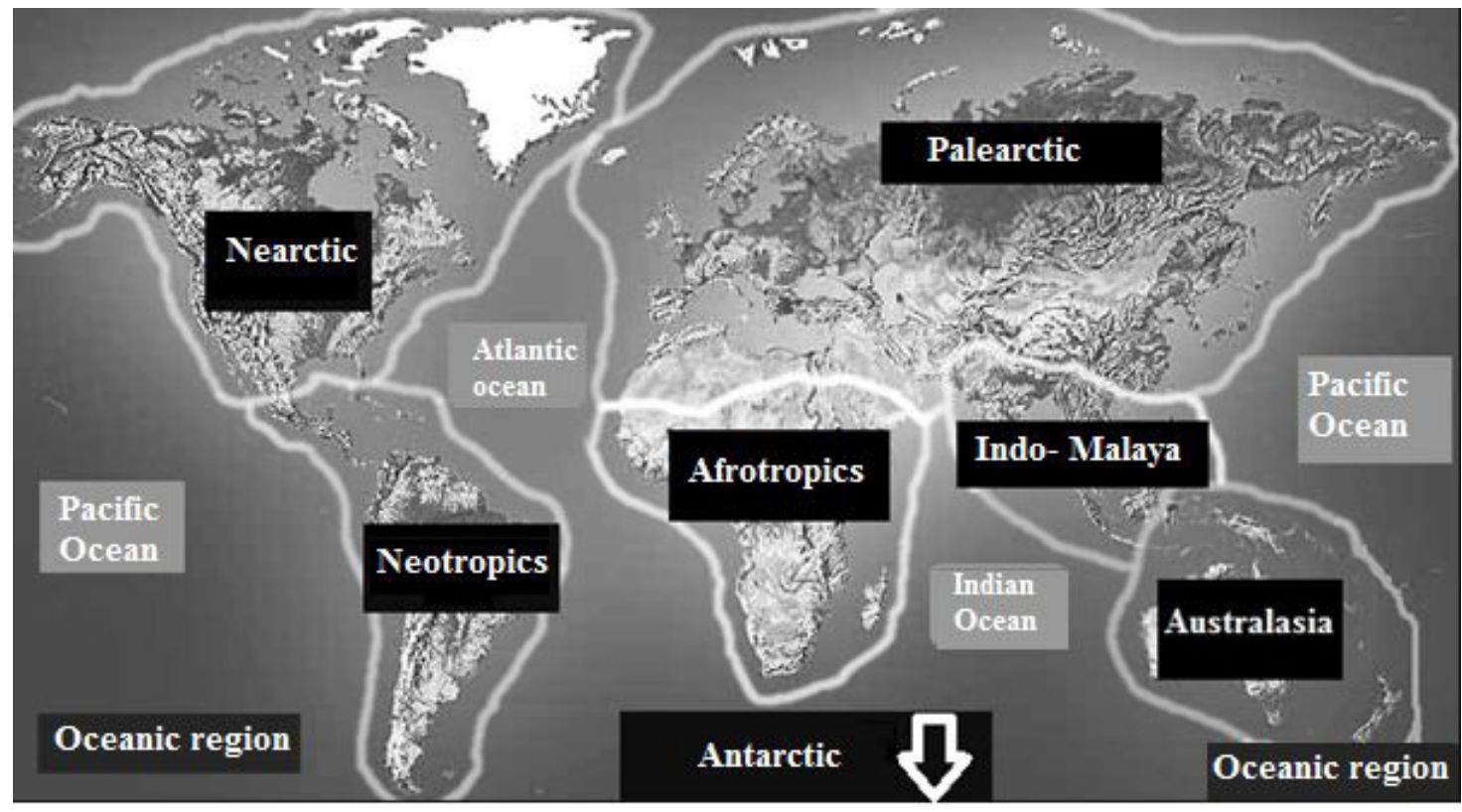

Note: Ecorregions are described on the black squares and the oceans on the gray squares. Source: Modified from INFOESCOLA (2010). 
Bora, L.S. et al.

\section{Supplementary material}

Complete table with all relationships characteristics is available from

https://sites.google.com/site/lablasb/

and ISI database

https://www.webofknowledge.com/ 